\title{
ISOLASI DAN SELEKSI BAKTERI PENGHASIL BIOSURFAKTAN YANG TERDAPAT DI DALAM DEPOSIT LILIN PADA PIPA TRANSMISI MINYAK MENTAH
}

\author{
Amilia'), Mardya Ning Tyas ${ }^{2)}$, Any Juliani, Andik Yulianto \\ Jurusan Teknik Lingkungan, FTSP \\ Universitas Islam Indonesia \\ Email: 1)amilia.envir08server@gmail.com; ${ }^{2)}$ Mardyaningtyaz@ymail.com
}

\begin{abstract}
ABSTRAK
Salah satu komponen berat di dalam minyak bumi yaitu parafin/wax akan mengendap pada dinding pipa transmisi apabila temperatur berkurang seiring minyak yang ditransmisikan mendekati permukaan bumi. Selain penanganan secara mekanis dan isolasi termal juga terdapat penangan dengan penambahan bahan kimia sejenis surfaktan untuk menurunkan tegangan permukaan kemudian membentuk mikroemulsi sehingga minyak dapat larut di dalam air begitu sebaliknya. Biosurfaktan menjadi alternatif menjanjikan yang ramah lingkungan, relatif mudah untuk dikembangkan dengan biaya yang relatif lebih murah. Tujuan dari penelitian ini yaitu menemukan isolat bakteri penghasil biosurfaktan menggunakan metode isolasi bakteri dari deposit lilin di dalam pipa transmisi minyak mentah kemudian diseleksi bakteri penghasil biosurfaktan. Didapatkan isolat bakteriEnterobacter gergoviaedanBurkholderia cepacia. Bakteri yang berkaitan dengan penghasil biosurfaktan disini yaitu bakteri Burkholderia cepacia yang memiliki waktu generasi 68,4 menit dengan konstanta laju pertumbuhan 0,61 per jam.

Kata Kunci : Deposit Lilin, Biosurfaktan, Bakteri Indigen
\end{abstract}

\section{ABSTRACT}

When transmitting crude oil, paraffin wax contained in the crude oil will be precipitated on the walls of the pipe as the crude closer to the earth's surface. Been applied mechanically handling, thermal insulation and with the addition of chemical inhibitors. The workings of a chemical inhibitor in addition to preventing the formation of wax crystals also lowers the temperature at which crude oil stopped flowing (crude pour point). As the working principle of the surfactant will reduce the surface tension so that then formed microemulsion oil soluble in water and oil soluble in water. From this surfactant can be applied to prevent wax precipitation. biosurfactant a promising alternative environmentally friendly, relatively easy to 
develop a relatively cheaper cost. The study was conducted to obtain biosurfactantproducing bacterial indigen isolates of wax deposition in crude oil transmission pipelines. Bacteria isolated from deposition wax then selected biosurfactant-producing bacteria by oil spreading technique and hemolysis test. Biosurfactant-producing bacteria Burkholderia cepacia bacteria are found.Burkholderia cepacia obtained with a generation time of 68.4 minutes and a constant growth rate of 0.61 per hour.

\section{Keywords: Wax Deposition, Biosurfactants, Bacteria Indigen}

\section{PENDAHULUAN}

Endapan dalam pipa tersebut biasanya diatasi dengan berbagai metode termasuk pembersihan secara mekanis, pengaplikasian panas dan uap ataupun penginjeksian bahan-bahan kimia termasuk jenis surfaktan yang dalam prosesnya membutuhkan biaya yang tidak sedikit. Salah satu alternatif pemecahan masalah yang dapat dikembangkan adalah dengan aplikasi proses biologis yang dalam hal ini dilakukan oleh mikroba jenis bakteri. Mikroba dapat dikembangkan untuk dapat mendegradasi endapan dalam pipa yang pada dasarnya adalah senyawa organik. Sementara itu, senyawa organik merupakan sumber karbon dan energi yang penting untuk mikroba. Namun aplikasi langsung tersebut terkendala kondisi lingkungan dalam pipa yang memiliki temperatur dan tekanan yang tinggi. Oleh karena itu proses biologis dapat diaplikasikan secara tidak langsung untuk mengatasi masalah ini melalui produksi biosurfaktan.
Bahan surfaktan telah lama dipakai oleh industri minyak untuk membantu proses bioremediasi limbah minyak serta digunakan dalam proses Enhanced Oil Recovery (EOR). Dalam proses bioremediasi, biosurfaktan digunakan untuk meningkatkan kelarutan polutan sehingga lebih mudah untuk didegradasi oleh mikroba. Dalam proses EOR, biosurfaktan dapat mengekstrak kembali minyak yang terjebak dalam substansi lain sehingga dapat meningkatkan produksi minyak dalam sumur minyak.

Biosurfaktan memiliki keunggulan dibandingkan dengan surfaktan yang disintesis secara kimiawi karena mempunyai kadar toksisitas yang rendah, dapat didegradasi secara biologis, efektif terhadap suhu, $\mathrm{pH}$ dan salinitas ekstrim, serta mudah disintesis. Biosurfaktan merupakan calon potensial untuk aplikasi komersial dalam industri obat-obatan dan makanan serta dalam industri pengambilan minyak. (Banat, 1995). 
Isolasi dan Seleksi Bakteri Penghasil..., Amilia, Mardya, Any, Andik

Penelitian ini dimaksudkan untuk memperoleh isolat murni bakteri penghasil biosurfaktan untuk mengatasi masalah endapan dalam pipa dengan pendekatan prinsip oil recovery. Kandungan minyak pada endapan diharapkan dapat direcovery dan dialirkan bersama aliran minyak serta mengurangi endapan dalam pipa. Biosurfaktan diisolasi dari bakteri indigen dalam sampel endapan pada pipa. Penggunaan bakteri indigen diharapkan dapat meningkatkan kemungkinan ditemukannya bakteri penghasil biosurfaktan, dimana bakteri-bakteri tersebut telah beradaptasi dengan substansi endapan serta kondisi lingkungan dalam pipa.

\section{METODOLOGI}

Pengambilan sampel endapan minyak mentah dalam pipa

Penelitian akan difokuskan pada isolasi, seleksi dan identifikasi bakteri penghasil biosurfaktan dan memiliki kemampuan terbaik dalam mengemulsikan minyak pada endapan minyak pada pipa transmisi minyak mentah. Tahapan penelitian disajikan dalam diagram alir pada gambar berikut:

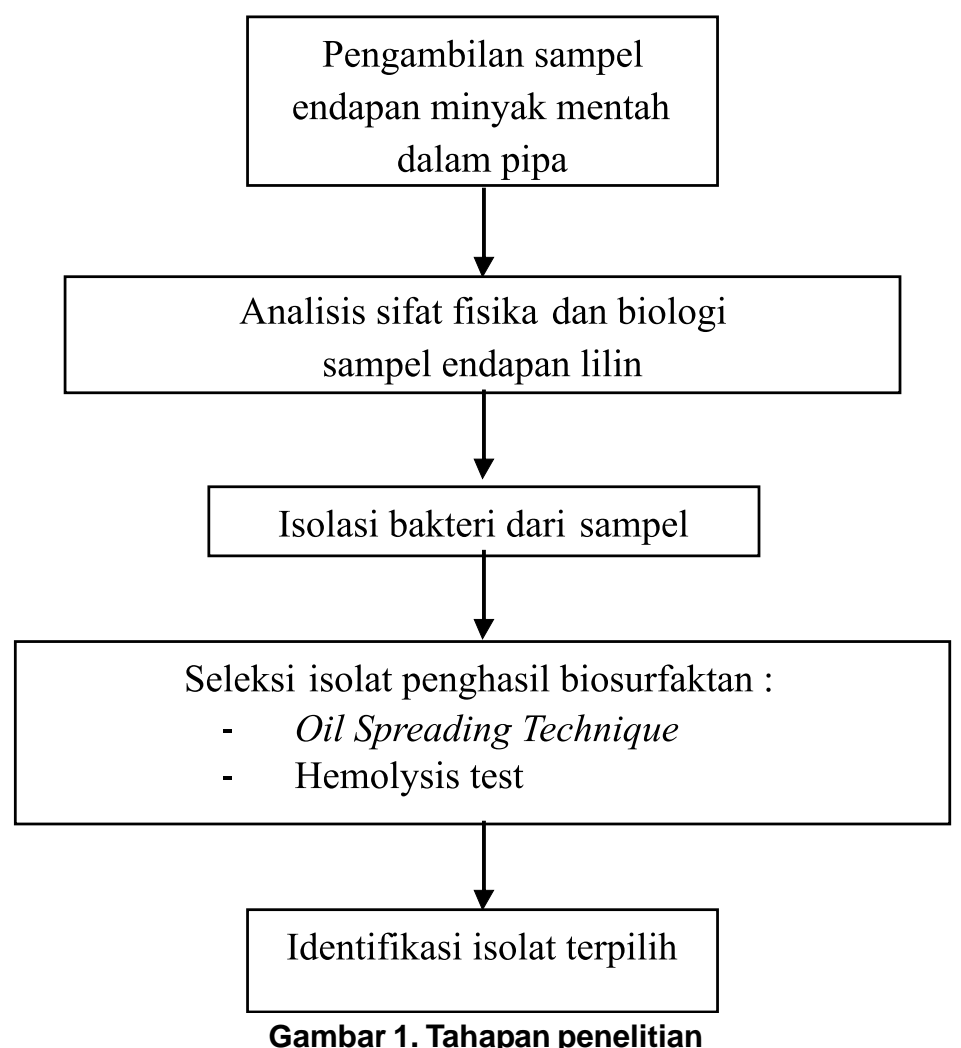


KHAZANAH, Vol. 5 No.2 Januari 2012

\section{Pengambilan sampel}

Sampel endapan minyak diambil dari pipa transmisi minyak mentah dari lapangan minyak di Makassar milik PT Chevron.

\section{Analisis sifat fisika}

Parameter fisika yang diperiksa adalah kadar air. Analisis dilakukan di laboratorium Mekanika Tanah, Jurusan Teknik Sipil, Universitas Islam Indonesia.

Pengukuran kadar air menggunakan SNI 03-1965-2008. Preparasi sampel dalam hal pengeringan dilakukan perubahan suhu yaitu pada standarnya $110 æ \% \mathrm{C} \pm 5 æ \% \mathrm{C}$ menjadi $60 æ \% \mathrm{C}$. Hal ini dilakukan untuk mempertahankan fasa awal sampel yaitu dalam fasa solid.

\section{Isolasi bakteri dari sampel}

Isolasi dilakukan dengan mengambil 5 gram sampel yang diinokulasikan dalam $50 \mathrm{ml}$ media. Terdapat tiga jenis media yang digunakan yaitu Media Basal (SNB), Nutrien Agar (NA), dan blood agar. Media SNB merupakan campuran dari Nutrient Broth dan media basal minimum dengan perbandingan 1 : 1 . Media basal minimum merupakan media yang dalam 1 liter akuades mengandung (Tabatabaee, 2005); 5 gr K $\mathrm{HPO}_{4}, 20 \mathrm{gr} \mathrm{KH}_{2} \mathrm{PO}_{4}, 30$ gr $\left(\mathrm{NH}_{4}\right)_{2} \mathrm{SO}_{4}, 0,1 \mathrm{gr} \mathrm{NaCl}, 0,2 \mathrm{gr}$ $\mathrm{MgSO}_{4} \cdot 7 \mathrm{H}_{2} \mathrm{O}, 0,01 \mathrm{gr} \mathrm{FeSO} \cdot 7 \mathrm{H}_{2} \mathrm{O}$, $0,01 \mathrm{gr} \mathrm{CaCl}_{2} \cdot 2 \mathrm{H}_{2} \mathrm{O}, \quad 0,2 \mathrm{gr}$ $\mathrm{MnSO}_{4} \cdot 7 \mathrm{H}_{2} \mathrm{O}, 0,03 \%$ glukosa dan 0,03
$\%$ yeast extract. Nilai $\mathrm{pH}$ media dikondisikan pada 7,2. Media yang telah diinokulasi dengan mikroba dikocok di atas shaker selama 2 jam supaya terjadi dispersi suspensi yang baik. Suspensi bakteri selanjutnya diencerkan dalam akuades steril secara serial dari $10^{-1}$ sampai $10^{-6}$. Sebanyak $1 \mathrm{ml}$ dari suspensi setiap pengenceran diinokulasikan ke atas media SNA (media SNB yang diberi agar sebanyak $15 \mathrm{gr} /$ liter media cair) dalam cawan petri. Petri selanjutnya diinkubasikan pada temperatur $30^{\circ} \mathrm{C}$ selama 48 jam. Media lain yang digunakan yaitu Nutrient Agar (NA). NA dibuat dengan mencampurkan Nutrien Broth 13,02 gr/liter dan Bacto Agar 15 gr/liter. Morfologi isolat yang muncul diamati dan dicatat. Selanjutnya dilakukan pemurnian kultur untuk mendapatkan isolat murni (pure culture). Sub kultur akan dilakukan secara periodik untuk menjaga viabilitas isolat.

\section{Seleksi isolat penghasil bio-} surfaktan

Isolat murni yang berhasil didapatkan pada tahap sebelumnya selanjutnya diseleksi untuk mendapatkan isolat yang mampu menghasilkan biosurfaktan. Seleksi dilakukan dengan menggunakan Oil Spreading Technique dan Uji Haemolysis.

\section{Oil Spreading Technique} (Anandaraj, 2010)

Mula-mula Isolat murni ditumbuhkan dalam media SNB selama 2 
Isolasi dan Seleksi Bakteri Penghasil..., Amilia, Mardya, Any, Andik

hari. Kultur selanjutnya disenstrifugasi. Teknik ini dilakukan dengan meletakkan $30 \mathrm{ml}$ akuades dalam cawan petri. Selanjutnya $1 \mathrm{ml}$ minyak kelapa dan minyak wijen diteteskan di bagian tengah dari cawan yang telah dibubuhi akuades. Lalu tambahkan supernatan.

\section{Tes Haemolisis}

Setiap isolat murni diinokulasikan dengan cara digesek pada media Blood Agar dalam cawan petri. Biakan bakteri diinkubasikan selama 48-72 jam pada $37^{\circ} \mathrm{C}$. Koloni yang tumbuh diamati. Isolat yang mampu menghasilkan biosurfaktan ditunjukkan dengan adanya zona yang bening di sekitar koloni. Isolat penghasil biosurfaktan selanjutnya diidentifikasi spesiesnya. Identifikasi isolat dilakukan di Balai Laboratorium Kesehatan Yogyakarta menggunakan VITEK 2 yang merupakan alat terotomatisasi untuk mengidentifikasi bakteri berdasarkan aktifitas biokimia dengan metode kolorimetri.

\section{HASIL DAN PEMBAHASAN}

Sampel yang diteliti merupakan endapan lilin (wax precipitation) pada

\section{Karakterisasi Bakteri}

Karakterisasi bakteri disini meliputi waktu generasi $(g)$ dan konstanta laju pertumbuhan $(k)$ isolat terpilih. Pengukuran jumlah bakteri dilakukan secara tidak langsung yaitu dengan membaca nilai kekeruhan isolat pada media cair yang kemudian akan didapatkan kurva pertumbuhan bakteri. Dari kurva pertumbuhan akan dilakukan linearisasi pada fase eksponensial pertumbuhan bakteri yang akan didapatkan slope kurva untuk mencari waktu generasi. Waktu generasi yang didapatkan sebagai data untuk mencari konstanta laju pertumbuhan dari isolat terpilih. Menggunakan formula berikut (Madigan et al, 2003):

$$
\begin{aligned}
& g=\frac{0,301}{\text { slope }} \\
& k=\frac{0,693}{g}
\end{aligned}
$$

pipa transmisi minyak mentah dimana memiki tipikal komposisi dan properti seperti disajikan pada tabel 1.

Tabel 1. Tipikal Komposisi dan Propertis Parafin wax dan Mikrokristalin wax

\begin{tabular}{|c|c|c|c|}
\hline No. & & Parafin Wax & Mikrokristalin Wax \\
\hline 1. & Normal Parafin (\%) & $80-95$ & $0-15$ \\
2. & Parafin bercabang (\%) & $2-15$ & $15-30$ \\
3. & Sikloparafin $(\%)$ & $2-8$ & $65-75$ \\
4. & Rentang Titik Leleh $\left({ }^{\circ} \mathrm{C}\right)$ & $50-65$ & $60-90$ \\
5. & Rentang rata-rata berat molekul & $350-430$ & $500-800$ \\
6. & Rentang tipikal jumlah karbon & $18-36$ & $30-60$ \\
7. & Rentang Pengkristalan (\%) & $80-90$ & $50-65$ \\
\hline
\end{tabular}


KHAZANAH, Vol. 5 No.2 Januari 2012

Tabel 2 Analisis Unsur Lilin dari Ekstraksi Minyak Diukur dengan C NMR (sampel dari beberapa titik pengambilan di Libya)

\begin{tabular}{|c|c|c|c|}
\hline No. & Wilayah & C (\% Berat) & H (\% Berat) \\
\hline 1. & Remal & 85,28 & 14,72 \\
2. & Bouri & 85,52 & 14,48 \\
3. & Sarir & 85,66 & 14,34 \\
4. & Sedra & 86,02 & 13,98 \\
5. & Faregh & 85,09 & 14,91 \\
\hline
\end{tabular}

\section{Analisis sifat fisika}

Makhluk hidup membutuhkan air demi kelangsungan hidupnya tidak terkecuali bakteri. Air berfungsi sebagai alat mengankut gizi dari luar ke dalam sel serta mengangkut hasil metabolik dari dalam sel ke luar. Kadar air erat hubungannya dengan lembab tidaknya suatu bahan. Semakin tinggi kadar air menyatakan suatu bahan semakin lembab. Bakteri senang hidup di medium yang lembab.
Kadar air yang berkaitan dengan pertumbuhan mikroba dinyatakan dalam aktifitas air (water activity). Namun sampel yang tidak diawetkan dan tidak segera mendapat perlakuan semenjak dilakukan pengambilan maka air yang terdapat pada sampel sangat dimungkinkan telah lepas sehingga dalam penentuan aktifitas air menjadi tidak relefan lagi.

Tabel 3 Hasil Analisis Sifat Fisika Sampel

\begin{tabular}{|c|l|c|c|}
\hline No. & Parameter Uji & Hasil & Formula \\
\hline 1. & Kadar air (w) & $5,86 \%$ & $\frac{W_{1}-W_{2}}{W_{2}-W_{3}} \times 100 \%$ \\
\hline
\end{tabular}

\section{Isolasi bakteri}

Isolasi bakteri dilakukan berulang kali hingga empat kali percobaan. Sampel yang diinokulasikan merupakan sampel yang telah melalui pengenceran berseri. Pengenceran berseri dilakukan 1000 hingga 1000000 kali pengenceran yang diinokulasikan secara aseptik dengan teknik tuang ke media SNA. Kemudian diinkubasi pada temperatur $30 æ \% \mathrm{C}$ selama 48 jam. Bentuk koloni yang tumbuh bervariasi, 
Isolasi dan Seleksi Bakteri Penghasil..., Amilia, Mardya, Any, Andik

yaitu Kekuningan, Circular, Permukaan halus mengkilap, koloni membentuk raised, tumbuh dipermukaan media, kumparan, dan adapun yang tumbuh pada dasar media.semua hasil isolat kemudian disubkultur menggunakan media SNB untuk mengetahui viabilitasnya.Isolat yang digunakan untuk tahap lebih lanjut merupakan isolat hasil dari percobaan ke-2 $\left(\mathrm{B}_{3}\right.$ dan $\left.\mathrm{B}_{4}\right)$, ke-3 $\left(\mathrm{C}_{13}\right)$, dan ke-4 $\left(D_{2}\right)$.

Jumlah bakteri berdasarkan metode pengukuran TPC menggunakan rumus jumlah koloni x faktor pengencer , maka jumlah relatif dengan untit $\mathrm{CFU} / \mathrm{ml}$ dapat dilihat pada tabel 4 .

Tabel 4 Hasil Uji TPC

Seleksi atau Screening

\begin{tabular}{|c|c|c|c|c|}
\hline No. & Sampel & Jumlah koloni & Pengencer & Hasil (CFU/ml) \\
\hline 1. & $\mathrm{~B}_{3}$ & 59 & $10^{3}$ & 59000 \\
\hline 2. & $\mathrm{~B}_{4}$ & 12 & $10^{4}$ & 120000 \\
\hline 3. & $\mathrm{C}_{13}$ & $>300$ & $10^{0}$ & $>300$ \\
\hline 4. & $\mathrm{D} 2$ & 237 & $10^{2}$ & 23700 \\
\hline
\end{tabular}

Pada proses seleksi dilakukan dua pengujian utama yaitu Oil Spreading Technique dan Haemolysis Test.

\section{Oil Spreading Technique}

Pada tahap oil spreading technique isolat yang digunakan adalah isolat $\mathrm{C}_{13}$ dan $\mathrm{B}_{4}$. Biakan $\mathrm{C}_{13} \mathrm{~A}$ dan $\mathrm{B}_{4} \mathrm{~A}$ disentrifugasi untuk menghasilkan supernatan. Teknik ini dilakukan dengan meletakkan $30 \mathrm{ml}$ akuades dalam cawan petri. Selanjutnya $1 \mathrm{ml}$ minyak kelapa dan minyak wijen diteteskan dibagian tengah cawan yang telah dibubuhi akuades. Lalu tambahkan supernatant. Pada pelaksanaan Oil Spreading Technique terlihat terjadinya pecahan pada minyak yang disebarkan pada plate yang mana hal ini menandakan bak- teri yang diinokulasikan melalui supernatan yang dimasukan memecah molekul minyak. Demikian halnya dengan tes hemolisis yang menggunakan blood agar - terbuat dari darah kambing - dimana terdapat koloni bakteri yang disekitarnya terbentuk area putih. Sebagaimana telah diketahui bahwa salah satu jenis biosurfaktan dapat memecahkan/me-lisis-kan eritrosit mamalia.

\section{Haemolysis Test}

- Pada tes haemolysis isolat murni $D_{1}$ dan $D_{2}$. Zona bening terbentuk disebabkan pada pengenceran $D_{1}$ dan $D_{2}$ merupakan pengenceran seri $10^{-1}$ dan $10^{2}$ yang dinokulasi ke media blood agar saat bakteri 
mengalami fase logaritma dimaana pada fase ini pembiakan bakteri berlangsung sangat cepat saat diisolasi sehingga baik untuk dijadikan inokulum pada media blood agar.

- Pada tes haemolysis isolat murni $D_{3}, D_{4}$ dan $D_{5}$. Pada isolat $D_{3}$ dan $\mathrm{D}_{5}$ mengalami pertumbuhan, hal ini diyakini karena saat proses pemindahan koloni sedang mengalami fase logaritma (sama halnya seperti $D_{1}$ dan $D_{2}$ ). Pada isolat $D_{4}$ tidak mengalami pertumbuhan. Diperkirakan bakteri mengalami kematian saat dipindahkan ke media blood agar, hal ini disebabkan oleh pemindahan menggunakan jarum ose dalam keadaan panas melebihi dari kemampuan pertahanan tubuh bakteri

- Pada tes haemolysis isolat murni $\mathrm{C}_{3}, \mathrm{C}_{4}$, dan $\mathrm{C}_{13}$. Pada isolat $\mathrm{C}_{3}$ tidak mengalami pertumbuhan, hal ini diperkirakan terjadi karena matinya bakteri saat pemindahan bakteri dari media isolasi ke media blood agar menggunakan jarum ose yang masih dalam kondisi panas melebihi dari kemampuan pertahanan tubuh bakteri. Hal ini diyakini dengan alasan dimana $\mathrm{C}_{3}$ dan $\mathrm{C}_{4}$ merupkan hasil isolat (duplo) yang samasama berasal dari pengenceran seri pertama $\left(10^{-1}{ }_{1}\right.$ dan $\left.10^{-1}{ }_{2}\right)$, namun pada $\mathrm{C}_{4}\left(10^{-1}{ }_{2}\right)$ mengalami pertumbuhan sedangkan $\mathrm{C}_{3}\left(10^{-1}{ }_{1}\right)$ tidak mengalami pertumbuhan.
- Pada tes haemolysis isolat murni $\mathrm{C}_{6}, \mathrm{C}_{8}$ dan $\mathrm{C}_{10}$. Pada isolat $\mathrm{C}_{6}$ danC $_{8}$ tidak mengalami pertumbuhan, hal ini kemungkinan terjadi dikarenakan pada saat isolasi $\mathrm{C}_{6}$ dan $\mathrm{C}_{8}$ mengalami fase kematian, yaitu dimana jumlah bakteri yang mati makin banyak dan makin melebihi jumlah bakteri yang membelah diri, Pada $C_{10}$ mengalami pertumbuhan namun pertumbuhannya sangat lambat, hal ini bisa saja terjadi dengan beberapa alasan, yaitu keadaan medium yang memburuk atau perubahan $\mathrm{pH}$, atau karena bertimbunnya zat kotoran, sehingga dapat menuyusutkan sel yang segar

- Pada tes haemolysis isolat murni $\mathrm{B}_{1}, \mathrm{~B}_{2}$ dan $\mathrm{B}_{3}$. Pada isolat $\mathrm{B}_{1}, \mathrm{~B}_{2}$ dan $B_{3}$ tidak mengalami pertumbuhan. Hal ini kemungkinan terjadi dikarenakan dua alasan, yang pertama yaitu pada saat isolasi zat makanan yang diperlukannya itu menjadi berkurang sehingga terjadi paceklik diantara mereka, alasan yang kedua adalah hasil ekskresi bakteri itu sendiri menjadi bertimbun-timbun, sehingga mengganggu pembiakan dan pertumbuhan.

- Pada tes haemolysis isolat murni $B_{4}, B_{5}$ dan $B_{6}$. Pada isolat $B_{5}$ tidak mengalami pertumbuhan, hal ini kemungkinan disebabkan oleh islolat yang mengalami kematian 
Isolasi dan Seleksi Bakteri Penghasil..., Amilia, Mardya, Any, Andik

saat pemindahan ke media blood agar, sedangkan pada $B_{4}$ dan $B_{6}$ mengalami pertumbuhan yang baik. Tes haemolisis yang menggunakan blood agar - terbuat dari darah kambing - dimana terdapat koloni bakteri yang disekitarnya terbentuk area bening. Sebagaimana telah diketahui bahwa salah satu jenis biosurfaktan dapat memecahkan/ me-lisis-kan eritrosit mamalia. Isolat yang menghasilkan bening pada zona sekitar koloni adalah $\mathrm{C}_{13}, \mathrm{~B}_{1}$, $\mathrm{B}_{2}, \mathrm{~B}_{3}, \mathrm{~B}_{4}$ dan $\mathrm{B}_{6}$.

\section{Karakterisasi Pertumbuhan Bakteri}

Isolat yang digunakan untuk biakan adalahC $C_{13}, D_{2}, B_{3}$ dan $B_{4}$. Pada panjang gelombang $600 \mathrm{~nm}$, keempat isolat pada $100 \mathrm{ml}$ NB diukur nilai absorbansinya. Pengukuran dilakukan setiap 3 jam selama 27 jam.

Masing-masing isolat memiliki tipe dalam lamanya melewati fase pertumbuhan. Untuk isolat $C_{13} A$ fase lag berlangsung selama 6 jam kemudian dilanjutkan fase eksponensial selama 12 jam. Untuk isolat $D_{2} A$ fase adaptasi selama 9 jam kemudian dilanjutkan fase eksponensial selama 12 jam. Isolat $\mathrm{B}_{2} \mathrm{~A}$ melewati fase adaptasi lebih lama yaitu selama 9 jam sama seperti isolat $D_{2} A$ yang kemudian dilanjutkan dengan fase eksponensial selama 12 jam juga. Untuk isolat $B_{4} A$ memiliki fase adaptasi 6 jam yang kemudian mulai menanjak pertumbuhannya selama 15 jam.

\section{Tabel 5 Pengukuran Bakteri Berdasarkan Kekeruhan}

\begin{tabular}{|c|c|c|c|c|c|c|c|c|c|c|c|c|c|}
\hline \multirow{3}{*}{ No. } & \multirow{3}{*}{ ID waktu } & \multicolumn{3}{|c|}{ Isolat $\mathrm{C}_{13} \mathrm{~A}$} & \multicolumn{3}{|c|}{ Isolat $D_{2} A$} & \multicolumn{3}{|c|}{ Isolat $\mathrm{B}_{3} \mathrm{~A}$} & \multicolumn{3}{|c|}{ Isolat $\mathrm{B}_{4} \mathrm{~A}$} \\
\hline & & $\begin{array}{c}\text { Rentang } \\
\text { Waktu }\end{array}$ & Abs & $\ln A$ & $\begin{array}{l}\text { Rentang } \\
\text { Waktu }\end{array}$ & Abs & $\ln A$ & $\begin{array}{l}\text { Rentang } \\
\text { Waktu }\end{array}$ & Abs & $\ln A$ & $\begin{array}{c}\text { Rentang } \\
\text { Waktu }\end{array}$ & Absorbansi & $\ln A$ \\
\hline & & (jam) & & & (jam) & & & (jam) & & & (jam) & & \\
\hline 1. & T0 & 0 & 0,016 & $-4,14$ & 0 & 0,015 & $-4,20$ & 0 & 0,02 & $-3,91$ & 0 & 0,012 & $-4,42$ \\
\hline 2. & $\mathrm{~T} 1$ & 3 & 0,024 & $-3,73$ & 3 & 0,025 & $-3,69$ & 3 & 0,036 & $-3,32$ & 3 & 0,03 & $-3,51$ \\
\hline 3. & $\mathrm{~T} 2$ & 6 & 0,061 & $-2,80$ & 6 & 0,028 & $-3,58$ & 6 & 0,037 & $-3,30$ & 6 & 0,065 & $-2,73$ \\
\hline 4. & T3 & 9 & 0,453 & $-0,79$ & 9 & 0,055 & $-2,90$ & 9 & 0,052 & $-2,96$ & 9 & 0,394 & $-0,93$ \\
\hline 5. & T4 & 12 & 0,941 & $-0,06$ & 12 & 0,215 & $-1,54$ & 12 & 0,157 & $-1,85$ & 12 & 0,783 & $-0,24$ \\
\hline 6. & T5 & 15 & 1,162 & 0,15 & 15 & 0,752 & $-0,29$ & 15 & 0,518 & $-0,66$ & 15 & 0,977 & $-0,02$ \\
\hline 7. & T6 & 18 & 1,241 & 0,22 & 18 & 1,082 & 0,08 & 18 & 0,974 & $-0,03$ & 18 & 1,105 & 0,10 \\
\hline 8. & $\mathrm{T7}$ & 21 & 1,249 & 0,22 & 21 & 1,284 & 0,25 & 21 & 1,24 & 0,22 & 21 & 1,17 & 0,16 \\
\hline 9. & T8 & 24 & 1,242 & 0,22 & 24 & 1,278 & 0,25 & 24 & 1,247 & 0,22 & 24 & 1,126 & 0,12 \\
\hline 10. & T9 & 27 & 1,229 & 0,21 & 27 & 1,262 & 0,23 & 27 & 1,256 & 0,23 & 27 & 1,12 & 0,11 \\
\hline 11. & $\mathrm{~T} 10$ & 30 & 1,215 & 0,19 & 30 & 1,257 & 0,23 & 30 & 1,247 & 0,22 & 30 & 1,103 & 0,10 \\
\hline
\end{tabular}


KHAZANAH, Vol. 5 No.2 Januari 2012

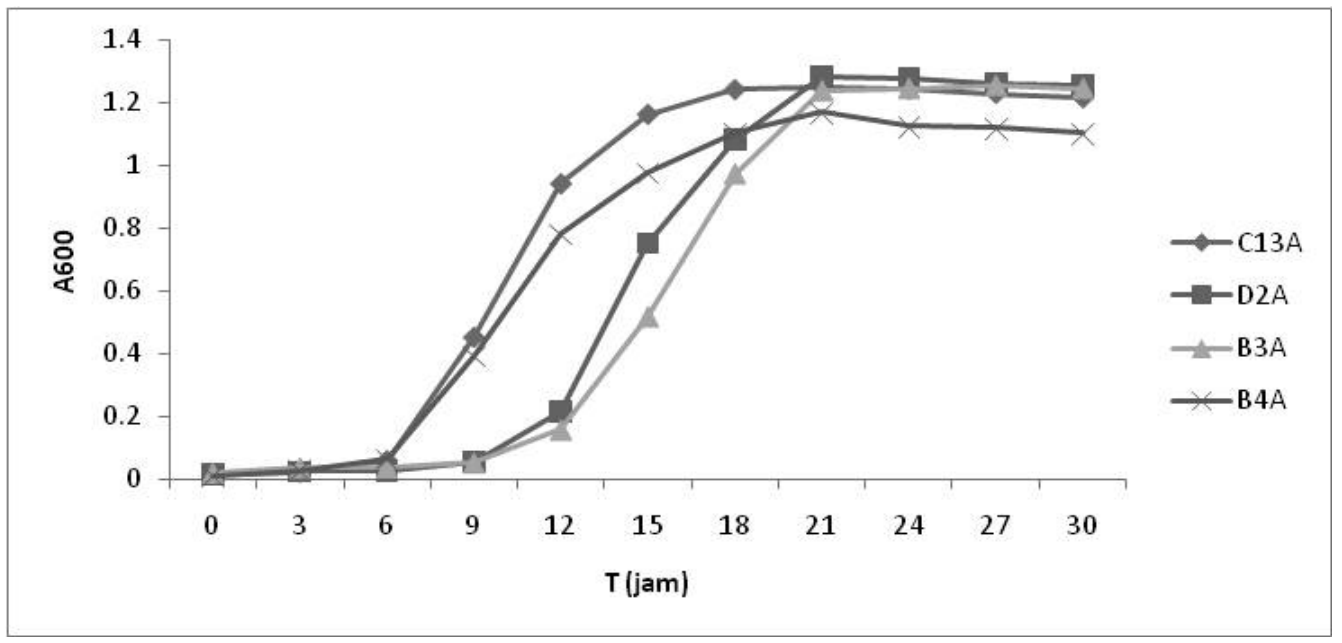

Gambar 2 Kurva Pertumbuhan Keempat Isolat

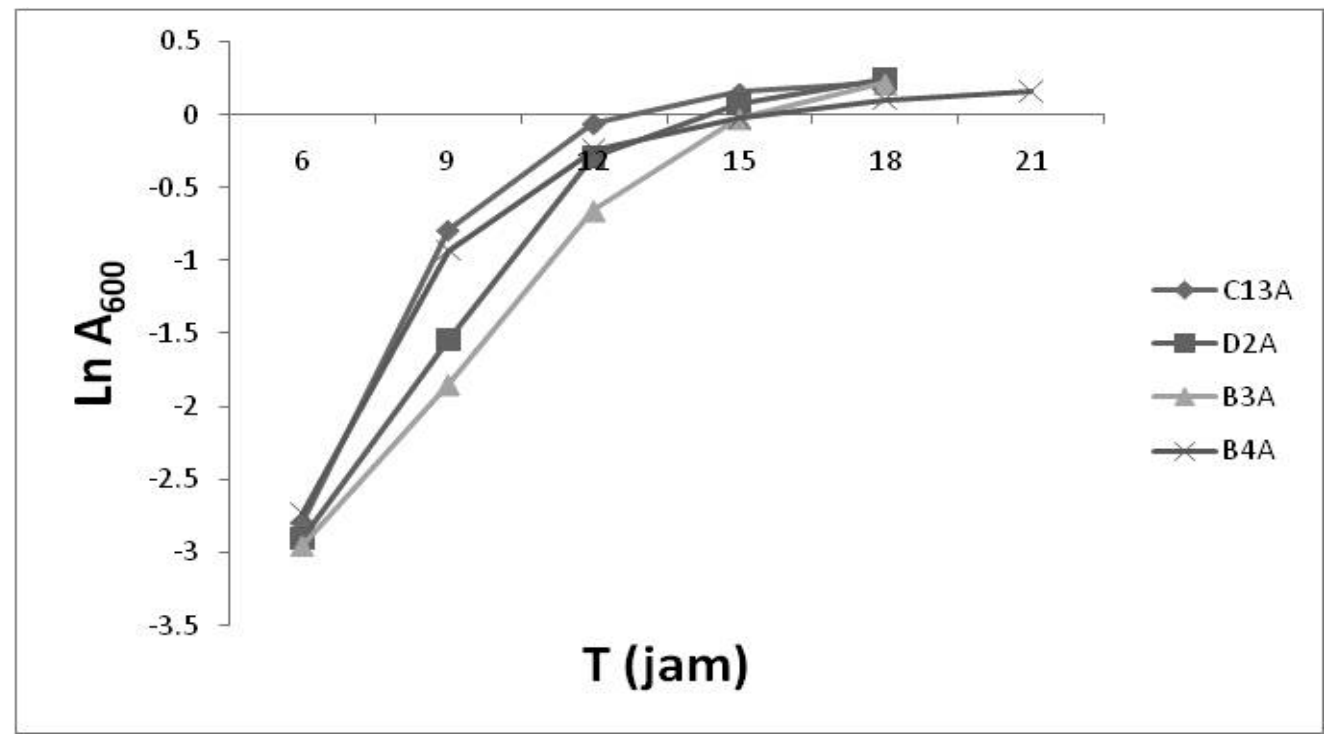

Gambar 3 Fase Eksponensial Keempat Isolat

Dari keempat isolat belum ada yang mencapai fase kematian. Metode pengukuran yang diterapkan disini menggunakan tingkat kekeruhan yang merupakan metode perhitungan pertumbuhan bakteri secara tidak langsung selain itu juga tidak membedakan antara sel yang mati dan sel yang hidup.
Pada Gambar 3 merupakan kurva dari pertumbuhan eksponensial. Untuk mendapatkan slope masing-masing kurva maka dilakukan linearisasi. Kurva ini digunakan untuk menentukan waktu generasi (g) dan konstanta laju pertubuhan bakteri (k). Nilai $\mathrm{g}$ dan $\mathrm{k}$ dapat dihitung dengan formula berikut (Madigan et al, 2003): 
Isolasi dan Seleksi Bakteri Penghasil..., Amilia, Mardya, Any, Andik

$$
\begin{aligned}
& g=\frac{0,301}{\text { slope }} \\
& k=\frac{0,693}{g}
\end{aligned}
$$

Tabel 6 Waktu Generasi dan Konstanta Laju Pertumbuhan Masing-Masing Isolat

\begin{tabular}{|c|c|c|c|c|}
\hline No. & Isolat & Slope & waktu generasi (jam) & konstanta laju pertumbuhan $\left(\right.$ jam $\left.^{-1}\right)$ \\
\hline 1 & $\mathrm{C}_{13} \mathrm{~A}$ & 0,2323 & 1,30 & 0,53 \\
\hline 2 & $\mathrm{D}_{2} \mathrm{~A}$ & 0,2639 & 1,14 & 0,61 \\
\hline 3 & $\mathrm{~B}_{3} \mathrm{~A}$ & 0,2723 & 1,11 & 0,63 \\
\hline 4 & $\mathrm{~B}_{4} \mathrm{~A}$ & 0,1692 & 1,78 & 0,39 \\
\hline
\end{tabular}

Waktu generasi masing-masing isolat berbeda berkisar antara 1,1 jam hingga 1,7 jam. Konstanta laju pertumbuhan bakteri juga berbeda beda tergantung pada kemampuan metabolisme dari bakeri itu sendiri. Konstanta laju pertumbuhan bakteri merupakan banyaknya bakteri yang tumbuh per unit waktu pada kultur yang tumbuh secara eksponensial. Laju pertumbuhan terendah terjadi pada isolat $C_{13} A$ dan yang tertinggi terjadi pada isolat $B_{3} A$. Pertumbuhan isolat $\mathrm{C}_{13} \mathrm{~A}$ yang lambat dapat diindikasikan bahwa telah terjadi kompetisi antara bakteri dalam memperebutkan substrat pada isolat $\mathrm{C}_{13} \mathrm{~A}$.

Dari sini kita dapat mengetahui fase pertumbuhan masing-masing isolat sehingga dapat menjadi pertimbangan jika akan dilakukan pemanfaatan bakteri yang lebih dari satu jenis maka perlu dipilih isolat bakteri yang berbeda fase eksponensialnya sehingga tidak terjadi kompetisi yang ketat dalam memperebutkan sumber karbon dalam minyak mentah karena dapat saling memperlambat pertumbuhan masingmasing bakteri itu sendiri.

\section{Identifikasi Spesies Bakteri}

Identifikasi spesies dengan menggunakan alat identifikasi bakteri yaitu VITEK 2 di Balai Laboratorium Kesehatan Yogyakarta. Dari lima isolat yang diidentifikasi, terdapat satu isolat yang tidak teridentifikasi. Keempat isolat lainnya yaitu Burkholderia cepacia dan tiga lainnya yaitu Enterobacter gergoviae.

Bakteri yang berkaitan dengan minyak bumi disini yaitu bakteri BurkhoIderia cepacia. Burkholderia cepacia merupakan jenis bakteri yang mampu mendegradasi/memecah rantai hidrokarbon dalam hal ini minyak bumi (disebut hidrokarbonuklastik). 
KHAZANAH, Vol. 5 No.2 Januari 2012

4

KESIMPULAN DAN SARAN

\section{KESIMPULAN}

Penelitian pengisolasian dan penyeleksian bakteri indigen dari sampel endapan lilin pada pipa transmisi minyak mentah ini didapatkan bahwa terdapat bakteri karbonoklastik pada sampel endapan lilin yang diteliti. Bakteri karbonoklastik merupakan bakteri yang dapat memecah rantai hidrokarbon. Kemampuan bakteri dalam memecah rantai hidrokarbon didahului oleh proses pelarutan hidrokarbon dalam fasa cair oleh surfaktan yang dihasilkan antara minyak dan mikroba tersebut.

Bakteri yang teridentifikasi sebagai Burkholderia cepacia merupakan isolat $D_{2} A$. Isolat $D_{2} A$ memiliki waktu generasi 1,14 jam atau 68,4 menit. Konstanta laju pertumbuhan bakteri ini yaitu 0,61 jam1.

\section{SARAN}

-Penelusuran lebih lanjut mengenai takaran komposisi trace elemen yaitu dari jenis logam yang tepat sebagai campuran media minimum sebagai substrat pertumbuhan bakteri.

Pengisolasian lebih lanjut untuk mengetahui kualitas bakteri hingga didapatkannya isolat terbaikdalam menghasilkan biosurfaktan.

\section{DAFTAR PUSTAKA}

Alghanduri, Elgarni, Daridon \& Coutinho (2010). Characterization of Libyan
Waxy Crude Oils. Energy FuelsEnergy\&Fuels Article. http:// path.web.ua.pt/file/ef1001937.pdf (5 November 2012)

Anandaraj, B. \& Thivakaran, P(2010). Isolation and Production of Biosurfactant Producing Organism From Oil Spilled Soil. Journal of Bioscience Technology, Vol 1(3).120126.

Badan Standarisasi Nasional (2008).

Cara Uji Penentuan Kadar Air untuk Tanah dan Batuan di Laboratorium. SNI 1965:2008.

Budiarti, R, S (2000). Optimasi Konsentrasi "Crude Oil" dan Sumber Nitrogen Pada Produksi Biosurfaktan Oleh Bakteri Hidrokarbonoklastik Dari Sumber Bangko. Tesis. Institut Teknologi Bandung.

Cookson J. T, Jr (1995). Bioremediation Engineering Design \& Application. McGraw Hill, Inc. USA

Dalimunthe, R (2002). Pengaruh Biosurfaktan Dalam Biodegradasi Limbah Minyak Bumi Oleh Mikroba Hidrokarbonoklastik. Tugas Akhir. Institut Teknologi Bandung.

Deleu, M, \& Paquot, M. 2004. From Renewable Vegetables Resources to Microorganisms: New Trends in Surfactants. C.R.Chimie.7: 641646

Dwipayana \& Ariesyady, H, W (2009). Identifikasi Keberagaman Bakteri pada Lumpur Hasil Pengolahan Limbah Cat dengan Teknik 
Isolasi dan Seleksi Bakteri Penghasil..., Amilia, Mardya, Any, Andik

Konvensional. Tugas Akhir. Institut Teknologi Bandung.

Helmy, Kardena, Nurachman, Wisjnuprapto (2010). Application of Biosurfactant Produced by Azotobacter vinelandii AV01 for Enhanced Oil Recovery and Biodegradation of Oil Sludge.International Journal of Civil \& Environmental Engineering IJCEE. Vol: 10 No: 01

Karanth, Deo, Veenanadig. 1999. Micro-

bial Production of Biosurfactants and Their Importance. Current Science, 77 (1). pp. 116-126

Koesoemadinata, R.P. (1980) Geologi Minyak dan Gas Bumi. Edisi kedua. Intitut Teknologi Bandung, Bandung. Muntohar, A, S (2012). Rekayasa Geoteknik-Struktur dan Komposisi Tanah. http://muntohar.files. wordpress. com/2008/09/bab2-limited.pdf (13 Oktober 2012).

Muthusamy, K. (2008). Biosurfactants: Properties, commercial production and application. Current Science. Vol. 94. No.6. Hal 736-739

Nursyirwani, \& Amolle, K, C (2007). Isolasi dan Karakterisasi Bakteri Hidrokarbonoklastik dari Perairan Dumai dengan Sekuen 16s rDNA. Jurnal IImu Kelautan. Vol 12 (1). 1217.

Pedersen, K, Fredenslund, Aa, Thomassen, P, (1989). Properties of Oils and Natural Gases. Gulf Publishing Company, Texas.

Pelczar, M, J, \& Chan, E, C, Jr (2008). Dasar-dasar Mikrobiologi. Universi- tas Indonesia.

Ruschau, Al-Anezi (2006). Oil and Gas Exploration and Production. http:// www.corrosioncost.com/pdf/ oilgas.pdf

S, Sudaryanto \& Utari, Ning (2012). Mengenal Sifat-Sifat Material (1) Struktur Kristal dan NonKristal. http://www.biomed.ee.itb.ac.id/ courses/Material\%20biomedika/ BAB $\% 207 \% 20 b 5 \%$

20 Struktur $\% 20 \mathrm{Kristal} \% 20 \mathrm{dan}$ \%20Nonkristal.pdf (13 Oktober 2012).

Singh, P, \& Cameotra, S, S, (2004). Potential Applications of Microbial Surfactants in Biomedical Sciences. TRENDSin Biotechnology. Vol. 22.No.3. Hal 142.

Syahri, Sugiarto (2008). Scale Treatment Pada Pipa Distribusi Crude Oil Secara Kimiawi. Seminar Nasional Teknoin 2008 Bidang Teknik Kimia dan Tekstil.

Tabatabaee, A, Assadi, M, Noohi, 